\title{
OBSERVATIONS ON THE NESTS AND PREY OF EUMENID WASPS (HYMENOPTERA, EUMENIDAE)*
}

\author{
BY HOWARD E. EVANS \\ Department of Zoology \& Entomology \\ Colorado State University \\ Fort Collins, Colo. 80523
}

The recent development of the techniques of trap-nesting have added greatly to knowledge of the biology of twig-nesting Eumenidae (e.g. Cooper, 1953, 1955; Krombein, 1967; Fye, 1965). However, only scattered information is available on species that nest in the ground or make free mud nests. Recent papers describing the behavior of North American ground-nesters include two on species of Stenodynerus (Evans, 1970; Clement, 1972) and two on species of Pterocheilus (Grissell, 1975; Evans, 1977). The present paper includes notes on a ground-nesting Pseudepipona and an aerialmud-nesting Parancistrocerus as well as on a mud nest built by a species of Euodynerus in a burrow dug by a sphecid wasp. This last example is described first.

\section{Euodynerus auranus (Cameron)}

Several females of this species were seen in a large blow-out in a dune area near Roggen, Weld Co., Colorado, on 2 August 1977. This blow-out was a major nesting site for the sphecid wasps Bembix pruinosa Fox and Philanthus albopilosus Cresson, but it seemed an unusual habitat for a eumenid. When a female Euodynerus auranus was seen to plunge into an open hole in sloping sand carrying a small caterpillar in her mandibles, she was captured and the hole excavated.

The burrow was apparently an abandoned, incipient nest of Bembix pruinosa, being of the form characteristic of that species and having a mound of sand on the down-slope side. The burrow terminated $15 \mathrm{~cm}$ from the entrance, at a depth of $5.5 \mathrm{~cm}$ from the surface directly above. In the bottom of the burrow was a single mud cell, open facing the burrow, measuring $9 \mathrm{~mm}$ in diameter

*Manuscript received by the editor January 26, 1978. 


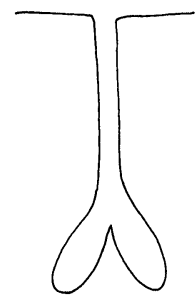

1

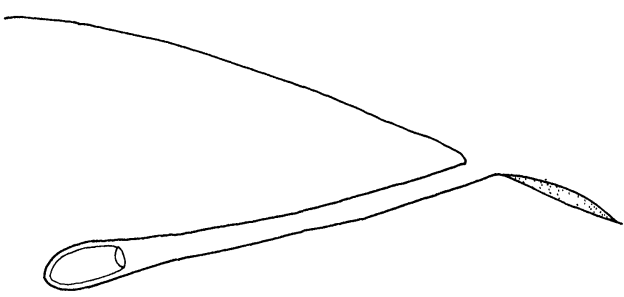

2

Figure 1. Diagram of nest of Pseudepipona herrichii, near Moran, Wyoming. Figure 2. Diagram of cell of Euodynerus auranus in abandoned burrow of Bembix pruinosa, near Roggen, Colorado.

and $16 \mathrm{~mm}$ in length (Fig. 2). It was extremely delicate, the walls measuring only $0.3 \mathrm{~mm}$ thick, smooth on the inside and slightly rough on the outside. The soil from which it was made was darker and more fine-grained than the surrounding sand, so had obviously been brought from some distance.

The cell contained 25 small, tightly coiled, paralyzed caterpillars of two species. These were identified as Filatima sp. (4) and near Anacampsis sp. (21) (both Gelechiidae). A wasp larva only $3.8 \mathrm{~mm}$ long was suspended by a short filament from the top wall of the cell $7 \mathrm{~mm}$ from its closed end. The larva was surely not more than a few hours old, but the fact that the female was still provisioning this nest demonstrates that this was an example of delayed provisioning, in the sense of Evans, 1966.

Bohart (1951) reported this species as making "clumps of five or six complete jug-shaped mud pots" in the ground (under the name Rygchium boscii auranum).

\section{Pseudepipona herrichii (Saussure)}

I observed 2 females of this Holarctic species nesting in the hard sandy loam of a path, 13-15 July 1977, in Grand Teton National Park, Wyoming, about $4 \mathrm{~km}$ WNW of the Moran Post Office. The path was in a meadow with sparse aspens and lodgepole pines, about $20 \mathrm{~m}$ from the banks of the Snake River. On the 13 th, one of the females was digging her nest, flying obliquely upward with small lumps of earth to a height of about $0.3 \mathrm{~m}$ and dropping the earth $0.6-0.9 \mathrm{~m}$ away. Two days later she was seen 


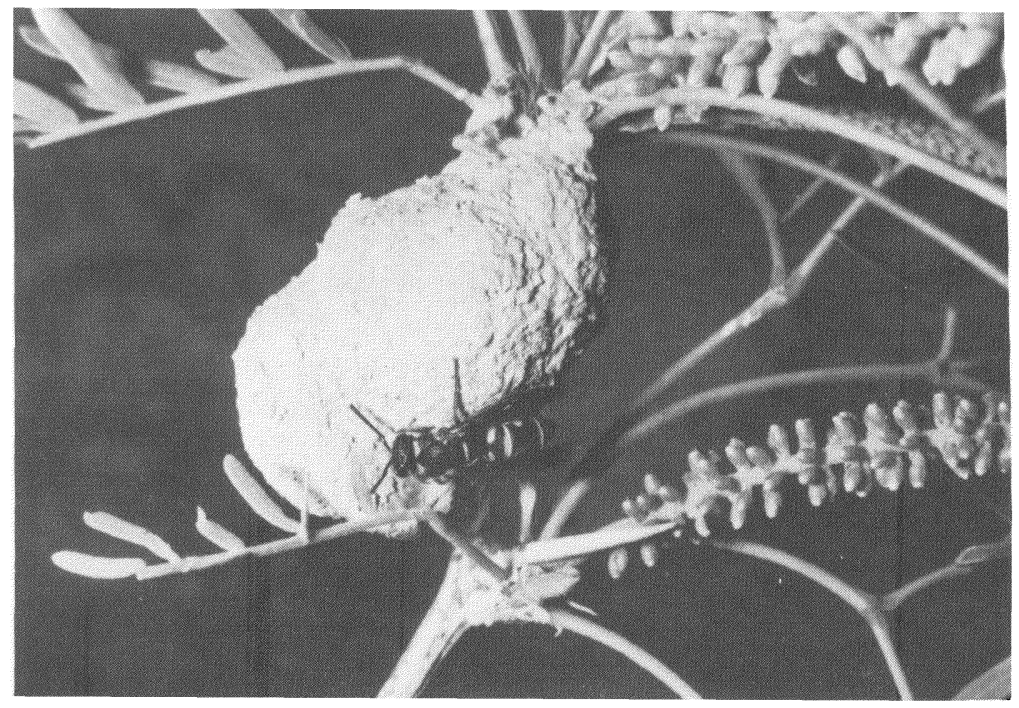

Figure 3. Nest of Parancistrocerus vagus on mesquite, Mescalero Sands, New Mexico.

provisioning the nest with small caterpillars carried in her mandibles. I captured her and excavated the nest, finding one cell with an egg and another with a rather large larva. Evidently the female had been digging the newer cell when first observed.

The burrow proved to be vertical, $6 \mathrm{~mm}$ in diameter, reaching a depth of only $5.5 \mathrm{~cm}$. The two cells diverged $4 \mathrm{~cm}$ down, each measuring $10 \mathrm{~mm}$ in diameter and $15 \mathrm{~mm}$ long (Fig. 1). The larva had nearly consumed all the prey in one cell, which was closed by a thin barrier of soil. The other cell contained 17 small, paralyzed caterpillars, all one species of Chionodes (Gelechiidae). The egg of the wasp measured $0.6 \times 2.3 \mathrm{~mm}$ and appeared to be loose toward the top of the cell, although I may have dislodged it during digging.

The second nest was only $7 \mathrm{~cm}$ away and was similar in dimensions except that there was only one cell. This cell had 5 caterpillars (Chionodes sp.) and presumable an egg, though I failed to find it. Caterpillars in both nests showed much movement but were unable to walk in a coordinated manner. Neither nest had any evidence of a turret at the entrance. 


\section{Parancistrocerus vagus (Saussure)}

Some years ago I reported briefly on a mud nest of this species found on a willow branch in Kansas (Evans, 1956). I take this opportunity to include a photograph of a very similar nest found on 4 June 1974 at Mescalero Sands, east of Roswell, New Mexico (Fig. 3). The nest was on the branch of a mesquite bush (Prosopis juliflora) $0.6 \mathrm{~m}$ above the ground. The nest measured $3.4 \times 1.9 \mathrm{~cm}$ and contained 6 cells, two of which were empty. Cells measured 6 . $\times 13 \mathrm{~mm}$. Two contained cocoons, one a large eumenid larva, and one nothing but dried, shriveled larvae of Microlepidoptera which were in too poor condition to be identified. The female wasp rested on the outside of the nest in a small hollow which would probably have formed the floor of a new cell.

The two cocoons both yielded cuckoo wasps, Chrysis dugesi Buysson, 2-3 weeks later.

\section{Discussion}

These three examples reinforce the impression that certain aspects of nesting behavior are relatively fixed in Eumenidae (oviposition and type of prey) while others are diverse and not closely correlated with generic divisions based on structure (location and type of nest). Eumenidae are largely solitary nesters, and it may be some years before enough information has accumulated to clarify the patterns of evolution within the group. The occurrence of delayed provisioning in Euodynerus auranus is of interest. This occurs in certain other Eumenidae and is regarded as one of several preadaptations for social life in wasps (Evans, 1958). Oviposition in the empty cell and use of materials from sources other than the immediate substrate provide other preadaptations; some Eumenidae use plant materials in nest construction (Bohart \& Stange, 1965). Species of Montezumia are evidently communal nesters and progressive provisioners (Evans, 1973). Thus there is every reason to regard the Eumenidae as providing the ancestral stock of the social Vespidae.

\section{ACKNOWLEDGMENTS}

I am indebted to R. M. Bohart for identifying the Eumenidae and Chrysididae and to D. M. Weisman for identifying the Lepi- 
doptera larvae. These observations were a by-product of studies of philanthine wasps, supported by the National Science Foundation, grant BNS76-09319.

\section{LITERATURE}

BOHART, R. M.

1951. Subfamily Eumeninae. In Muesebeck, C. F. W., et al. Hymenoptera of America North of Mexico: Synoptic Catalog. U.S. Dept. Agri. Monogr. 2, pp. 884-907.

Bohart, R. M. and Stange, L. A.

1965. A revision of the genus Zethus in the western hemisphere. Univ. Calif. Publ. Ent., 40: 1-208.

Clement, S. L.

1972. Notes on the biology and larval morphology of Stenodynerus canus canus (Hymenoptera: Eumenidae). Pan-Pac. Ent., 48: 271-276.

COOPER, K. W.

1953, 1955. Biology of eumenine wasps. I, II. Trans. Amer. Ent. Soc., 79: 13-35; 80: 119-174.

Evans, H. E.

1956. Notes on the biology of four species of ground-nesting Vespidae (Hymenoptera). Proc. Ent. Soc. Wash., 58: 165-270.

1958. The evolution of social life in wasps. Proc. 10th Internat. Congress Ent., 2: 449-457.

1966. The Comparative Ethology and Evolution of the Sand Wasps. Harvard Univ. Press, Cambridge, Mass. 526 pp.

1970. Ecological-behavioral studies of the wasps of Jackson Hole, Wyoming. Bull. Mus. Comp. Zool. Harvard, 140: 451-511.

1973. Notes on the nests of Montezumia (Hymenoptera, Eumenidae). Ent. News, 84: 285-290.

1977. Notes on the nesting behavior and immature stages of two species of Pterocheilus (Hymenoptera: Eumenidae). Jour. Kansas Ent. Soc., 50: 329-334.

FYE, R. E.

1965. The biology of the Vespidae, Pompilidae, and Sphecidae (Hymenoptera) from trap nests in northwestern Ontario. Canad. Ent., 97: 716744.

GRISSELL, E. E.

1975. Ethology and larva of Pterocheilus texanus (Hymenoptera: Eumenidae). Jour. Kansas Ent. Soc., 48: 244-253.

Krombein, K. V.

1967. Trap-nesting Wasps and Bees: Life Histories, Nests, and Associates. Smithsonian Press, Washington, D.C. 570 pp. 

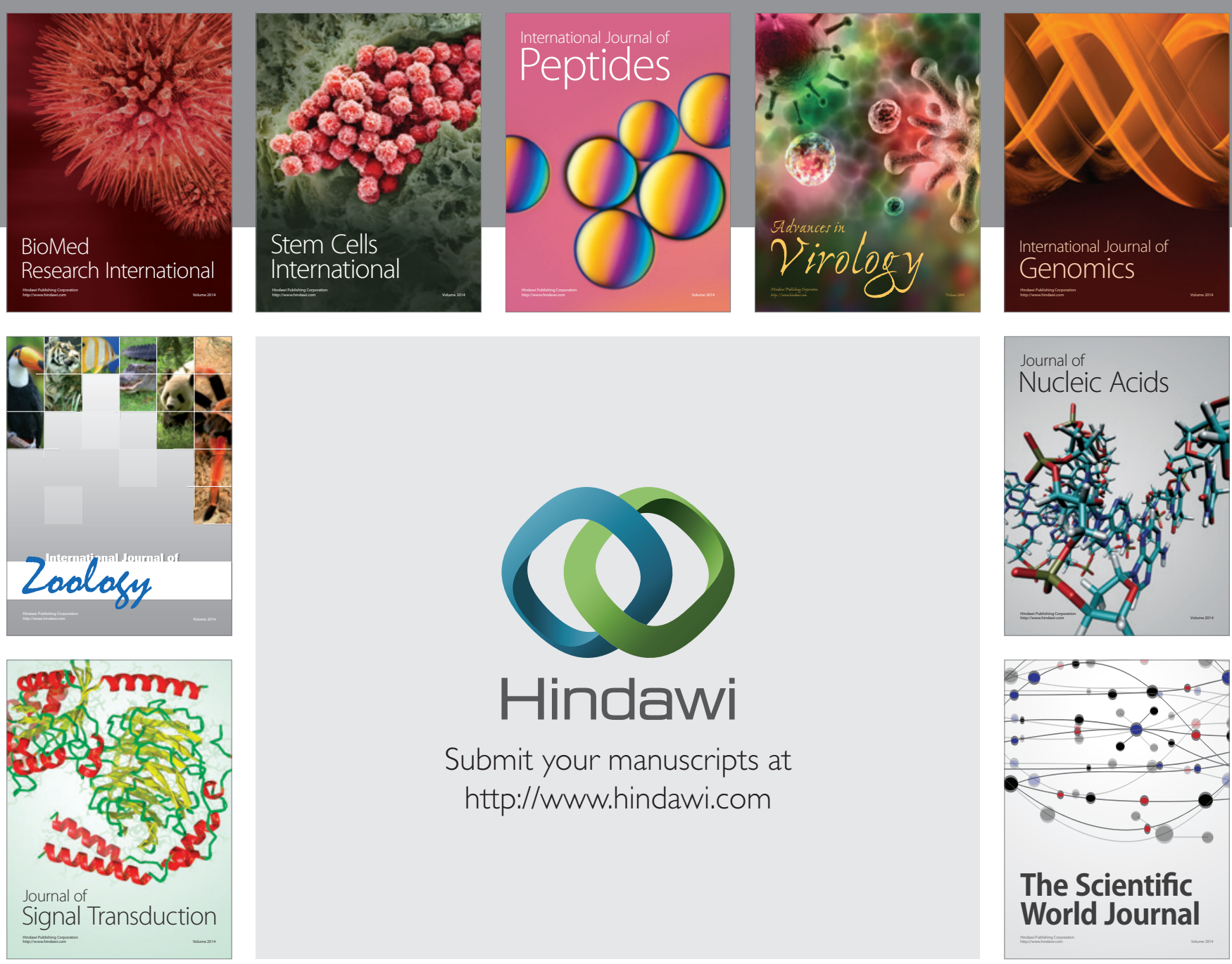

Submit your manuscripts at

http://www.hindawi.com
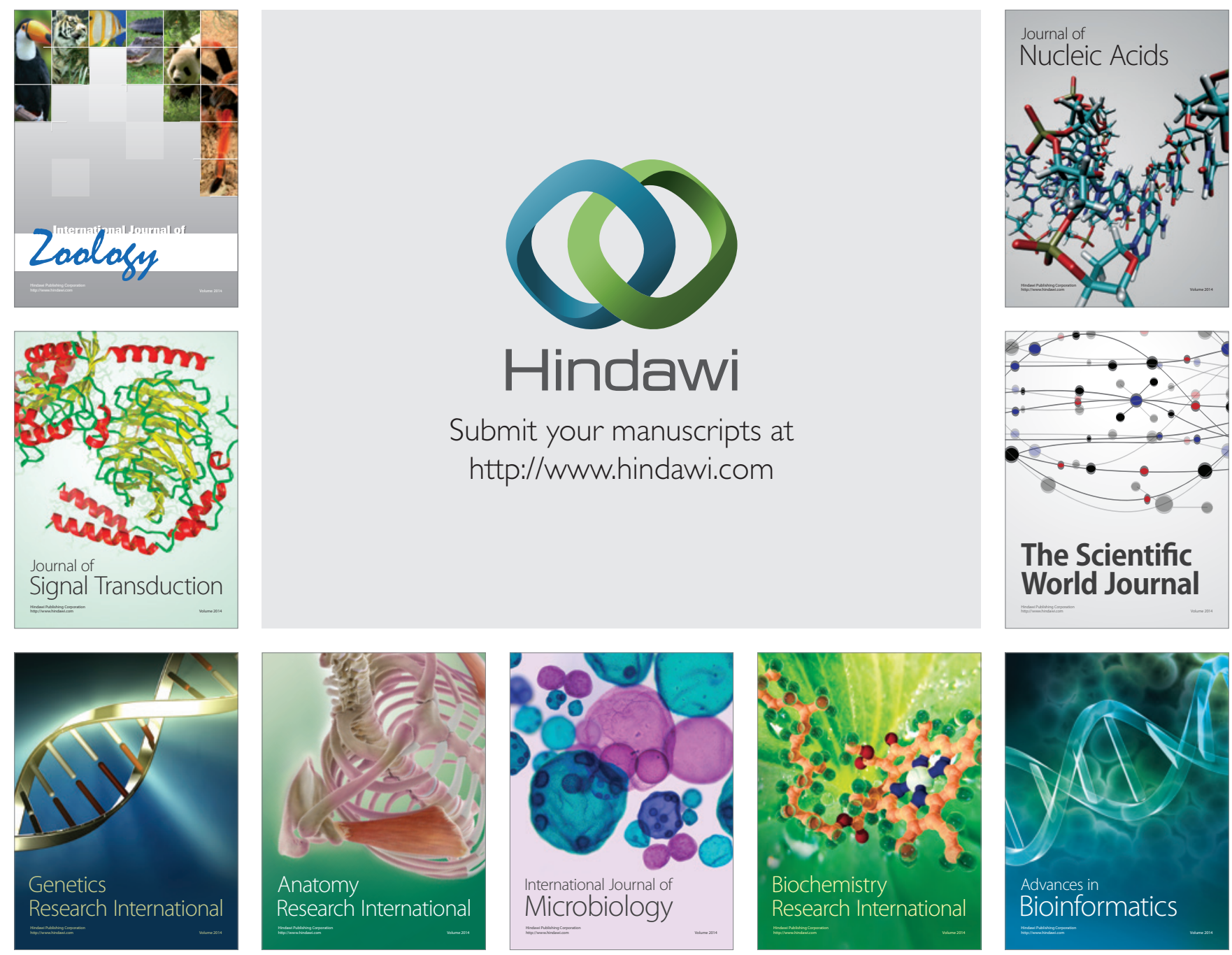

The Scientific World Journal
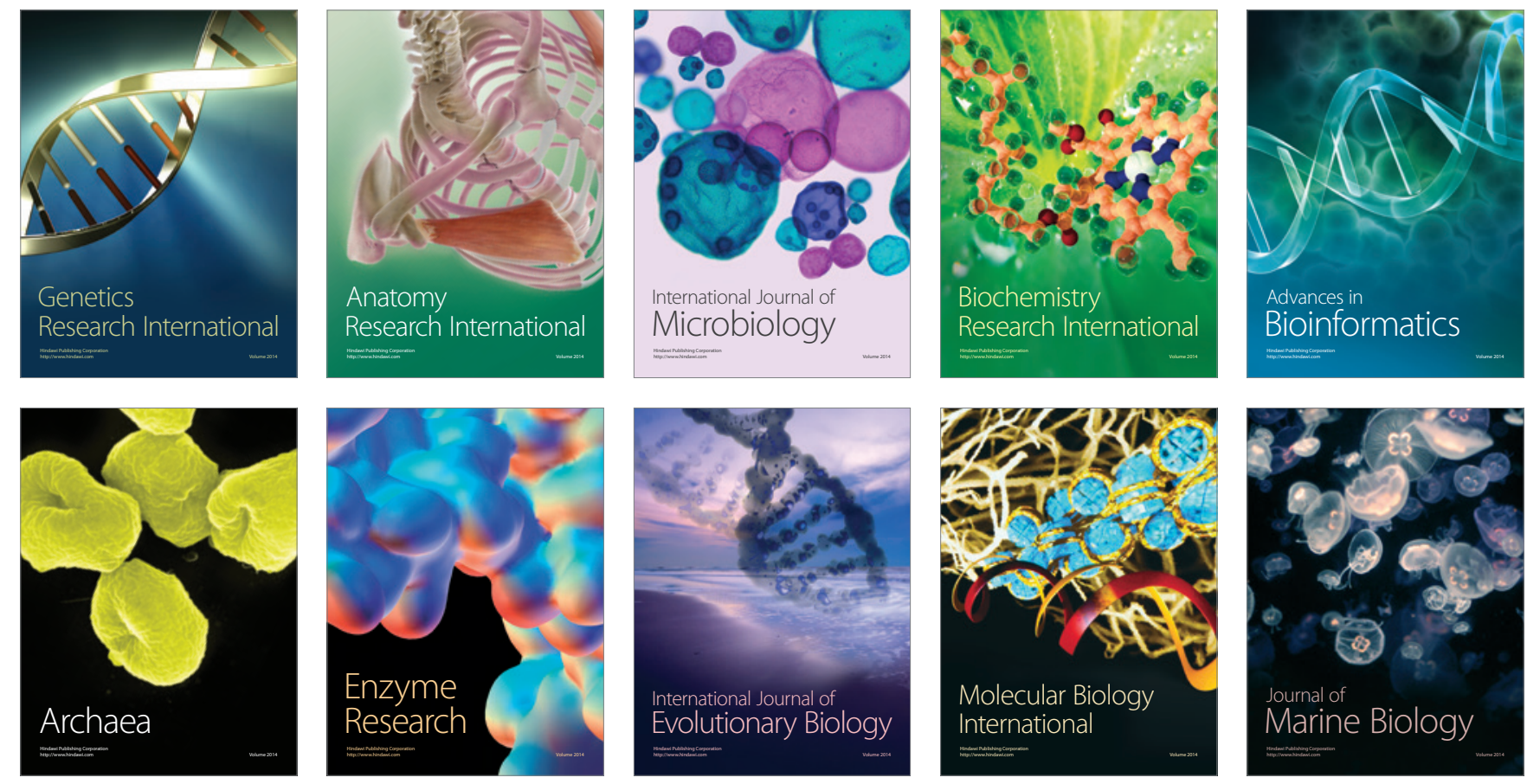